\title{
CORRELATION BETWEEN THE MORPHOMETRIC PARAMETERS OF MAXILLARY SINUSES AND NASAL APERTURES AS A FORENSIC IDENTIFICATION AID USING CONE BEAM CT: A PILOT STUDY
}

\begin{abstract}
Objectives: Bone remodelling of the cranium determines the enlargement of the maxillary sinuses. The process involves the resorption of the internal walls of the maxillary sinus that slightly exceed the growth of the maxilla. During this process, bone deposition occurs at the medial border of the nasal cavity as does simultaneous resorption of the lateral wall of the nasal cavity. Very few studies have investigated the correlation between the growth of the maxillary sinuses with changes in the dimensions of the nasal aperture. Therefore, the present study aimed to determine, compare and correlate the three-dimensional morphometric parameters of the maxillary sinus and nasal apertures in a study population from the states of Karnataka and Kerala in India, to utilize the data for the purpose of individual identification, sexual dimorphism or any other application in the field of forensic facial reconstruction and/or human identification.
\end{abstract}

Materials and Methods: This pilot study analysed the measurements of the morphometric landmarks of the maxillary sinus and the nasal aperture of 20 subjects, ranging in age from 18 to 30 .

Results: The Morphometric parameters of the maxillary sinus and the nasal aperture were seen to be statistically significant in a few of the groups, and these findings can be applied to evaluate sexual dimorphism.

Conclusions: The maxillary sinuses remain intact even though the skull and other bones of the cranium may be severely disfigured in victims that are incinerated or that have experienced external trauma. Morphometric measurements, such as width, depth and height which were used to investigate the accuracy and reliability of the maxillary sinuses, can also be used for sex estimation. These dimensions can be correlated with the measurements of the nasal aperture, which will also provide an insight into the development of the cranium. Moreover, these measurements are important anthropometric parameters for classifying the race and sex of an individual whose identity is unknown.
D Mahabalesh Shetty $\mathrm{K}^{1}$

* Kumuda $\mathrm{Rao}^{2}$

Krishna Nayak ${ }^{3}$

ORCID IDs of the authors:

M.S.K. 0000-0003-3271-4844

K.R. $\quad 0000-0002-6214-1381$

K.N. 0000-0001-7551-0994

1 Department of Forensic Medicine and Toxicology, NITTE deemed to be University, K S Hegde Medical Academy, Mangalore

2 Department of Oral Medicine and Radiology, NITTE deemed to be University, $\mathrm{AB}$ Shetty Memorial Institute of Dental Sciences, Deralakatte, Mangalore

${ }^{3}$ NITTE deemed to be University, AB Shetty Memorial Institute of Dental Sciences

Received : : 30.09 .2020

Accepted $\quad: 18.12 .2020$

Key words: maxillary sinus, nasal cavity, forensic, facial, reconstruction, morphometric measurements.

How to Cite: Shetty KM, Rao K, Nayak K. Correlation Between Morphometric Parameters of Maxillary Sinus and Nasal Aperture as an Aid to Forensic Identification Using Cone Beam Ct: A Pilot Study. Cumhuriyet Dent J 2021;24:1:30-36.

*Corresponding Author:

Department of Oral Medicine and Radiology, NITTE deemed to be University, AB Shetty Memorial Institute of Dental Sciences, Deralakatte, Mangalore

E-mail: drkumudarao@yahoo.in 


\section{INTRODUCTION}

Maxillary sinuses play an important role in victims whose bodies have been incinerated but reported to stay intact even in severely disfigured and incinerated skulls. ${ }^{1}$ The morphometric measurements that are used to estimate the indices of the maxillary sinus parameters are the width, depth and height of the maxillary sinuses; these can also be used for sex estimation and other forensic applications. ${ }^{2}$ The shapes and sizes of the human nose vary with ethnicity, and these have a direct impact on facial appearance. Nasal parameters are important for anthropometry, and they can be applied for classifying the race and sex of an individual whose identity is unknown. Hence, we conducted this study to determine and correlate the morphometric measurements of the nasal cavity and the maxillary sinus using Cone Beam Computed Tomography (CBCT) in subjects from the states of Karnataka and Kerala in India. The results can be applied to estimate the sex of individuals whose identity is unknown in the population under study.

\section{MATERIALS AND METHODS}

CBCT data of 20 subjects from the states of Karnataka and Kerala in India were collected from the Department of Oral Medicine and Radiology. CBCT data acquisition was done using ProMax 3D Mid (Planmeca, Helsinki, Finland). The standard protocol was used: Full field of view 200 x $170 \mathrm{~cm}$; voxel size $400 \mathrm{~mm}$; exposure time 4.7 seconds. Hard tissue and soft tissue landmarks of the nose were marked, and morphometric measurements were obtained using NEMOCEPH 3D-the exclusive Cephalometric and Orthodontic Analysis software of Nemostudio: The Digital Medical Company. The parameters were analysed as per the stated objectives of the study. The subjects included in the study ranged in age between 18 and 30; they had no congenital anomalies/syndromes, oro-facial pathologies, orthodontic correction, history of trauma, surgical intervention or exposure to radiotherapy.

Ethical clearance was obtained from the Institutional Review Board, dated 20.11.2018. Informed consent and subject information sheets were obtained from all the subjects that who participated in the study.

\section{STATISTICAL ANALYSIS METHOD}

The mean, standard deviation and standard error, along with the confidence interval of the craniometric (skull) and capulometric (soft tissue) measurements of the nasal aperture and maxillary sinus, were documented. The comparison of various measurements of the nose the maxillary sinuses between the sexes (Table 1) and the two states (Table 2) was done by using the student $t$ test.

Table 1. Comparison between gender

\begin{tabular}{|c|c|c|c|c|c|c|c|c|c|c|c|}
\hline & & \multirow[t]{2}{*}{ Sex } & \multirow[t]{2}{*}{$\mathbf{N}$} & \multirow[t]{2}{*}{ Mean } & \multirow[t]{2}{*}{ SD } & \multirow[t]{2}{*}{$\begin{array}{c}\text { Mean } \\
\text { Difference }\end{array}$} & \multicolumn{2}{|c|}{$\begin{array}{l}\text { 95\% Confidence } \\
\text { Interval of the } \\
\text { Difference }\end{array}$} & \multirow[t]{2}{*}{$\mathbf{t}$} & \multirow[t]{2}{*}{ df } & \multirow[t]{2}{*}{ p-value } \\
\hline & & & & & & & Lower & Upper & & & \\
\hline \multirow{2}{*}{$\begin{array}{c}\text { Height - } \\
\text { MS }\end{array}$} & Right & $\begin{array}{l}1 \\
2\end{array}$ & $\begin{array}{c}8 \\
12\end{array}$ & $\begin{array}{l}37.41 \\
34.16\end{array}$ & $\begin{array}{l}5.49 \\
2.89\end{array}$ & 3.25 & -0.68 & 7.18 & 1.74 & 18 & $0.10(\mathrm{NS})$ \\
\hline & Left & $\begin{array}{l}1 \\
2\end{array}$ & $\begin{array}{c}8 \\
12\end{array}$ & $\begin{array}{l}38.43 \\
35.56\end{array}$ & $\begin{array}{l}3.15 \\
2.74\end{array}$ & 2.87 & 0.09 & 5.66 & 2.17 & 18 & $0.04 *$ \\
\hline \multirow{2}{*}{$\begin{array}{l}\text { Width - } \\
\text { MS }\end{array}$} & Right & $\begin{array}{l}1 \\
2\end{array}$ & $\begin{array}{c}8 \\
12\end{array}$ & $\begin{array}{l}28.59 \\
28.26\end{array}$ & $\begin{array}{l}4.52 \\
3.54\end{array}$ & 0.33 & -3.46 & 4.12 & 0.18 & 18 & $0.86(\mathrm{NS})$ \\
\hline & Left & $\begin{array}{l}1 \\
2\end{array}$ & $\begin{array}{c}8 \\
12\end{array}$ & $\begin{array}{l}30.20 \\
29.33\end{array}$ & $\begin{array}{l}4.85 \\
3.63\end{array}$ & 0.87 & -3.11 & 4.84 & 0.46 & 18 & $0.65(\mathrm{NS})$ \\
\hline \multirow{2}{*}{$\begin{array}{c}\text { Depth - } \\
\text { MS }\end{array}$} & Right & $\begin{array}{l}1 \\
2\end{array}$ & $\begin{array}{c}8 \\
12\end{array}$ & $\begin{array}{l}39.57 \\
37.40\end{array}$ & $\begin{array}{l}3.40 \\
3.14\end{array}$ & 2.16 & -0.95 & 5.28 & 1.46 & 18 & $0.16(\mathrm{NS})$ \\
\hline & Left & $\begin{array}{l}1 \\
2\end{array}$ & $\begin{array}{c}8 \\
12\end{array}$ & $\begin{array}{l}40.53 \\
38.47\end{array}$ & $\begin{array}{l}2.41 \\
2.38\end{array}$ & 2.06 & -0.23 & 4.35 & 1.89 & 18 & $0.08(\mathrm{NS})$ \\
\hline $\mathbf{N A}$ & Height & $\begin{array}{l}1 \\
2\end{array}$ & $\begin{array}{c}8 \\
12\end{array}$ & $\begin{array}{l}40.81 \\
36.00\end{array}$ & $\begin{array}{l}3.97 \\
1.30\end{array}$ & 4.81 & 2.24 & 7.37 & 3.93 & 18 & $0.001 *$ \\
\hline INA & Width & $\begin{array}{l}1 \\
2\end{array}$ & $\begin{array}{c}8 \\
12\end{array}$ & $\begin{array}{l}24.81 \\
23.36\end{array}$ & $\begin{array}{l}2.30 \\
1.99\end{array}$ & 1.45 & -0.57 & 3.48 & 1.51 & 18 & $0.15(\mathrm{NS})$ \\
\hline
\end{tabular}


Table 2. Comparison between states

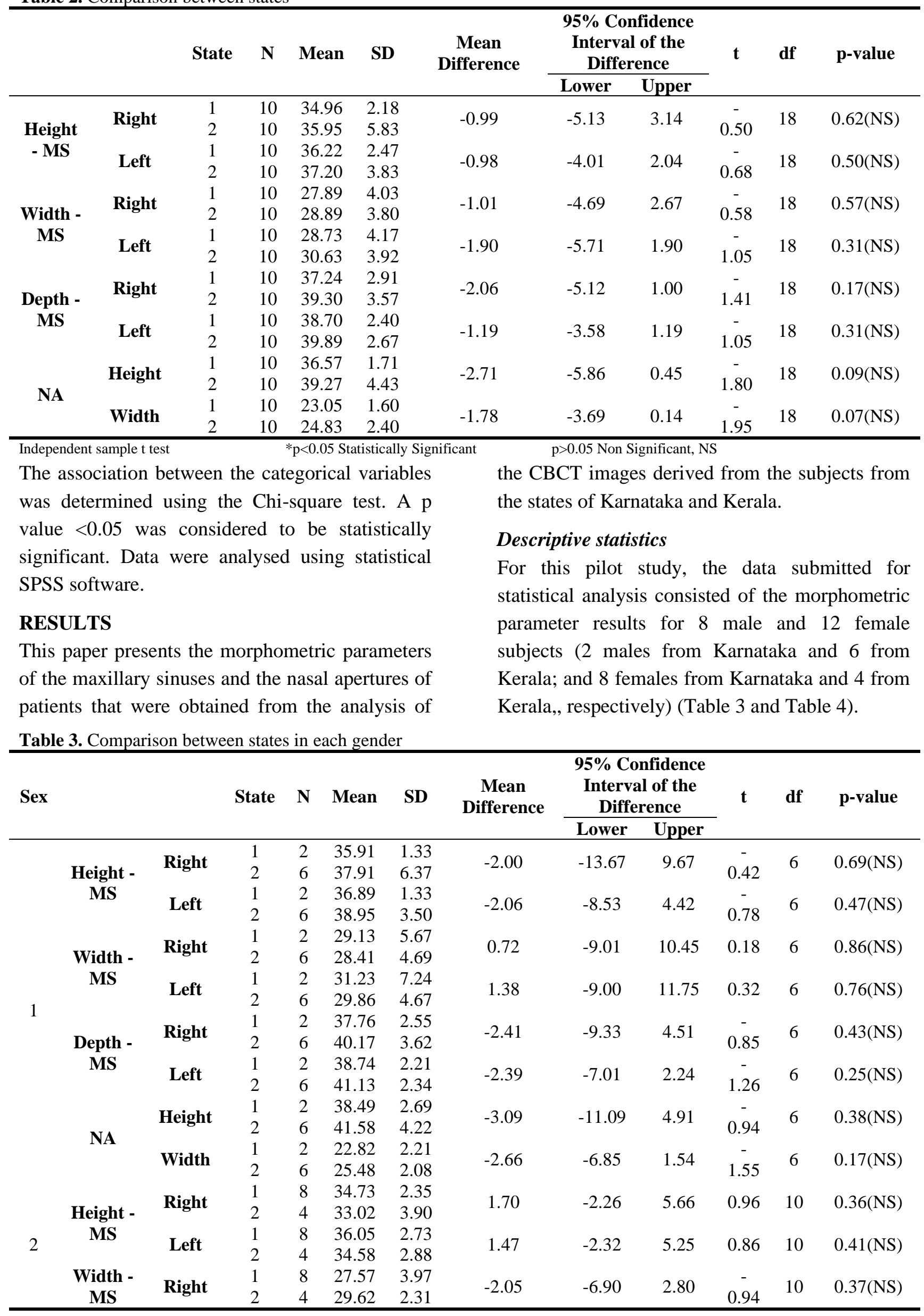




\begin{tabular}{|c|c|c|c|c|c|c|c|c|c|c|c|}
\hline & Left & $\begin{array}{l}1 \\
2\end{array}$ & $\begin{array}{l}8 \\
4\end{array}$ & $\begin{array}{l}28.10 \\
31.79\end{array}$ & $\begin{array}{l}3.56 \\
2.57\end{array}$ & -3.69 & -8.18 & 0.80 & $\begin{array}{c}- \\
1.83\end{array}$ & 10 & $0.10(\mathrm{NS})$ \\
\hline \multirow{2}{*}{$\begin{array}{l}\text { Depth - } \\
\text { MS }\end{array}$} & Right & $\begin{array}{l}1 \\
2\end{array}$ & $\begin{array}{l}8 \\
4\end{array}$ & $\begin{array}{l}37.11 \\
37.99\end{array}$ & $\begin{array}{l}3.14 \\
3.55\end{array}$ & -0.88 & -5.34 & 3.58 & $\begin{array}{c}- \\
0.44\end{array}$ & 10 & $0.67(\mathrm{NS})$ \\
\hline & Left & $\begin{array}{l}1 \\
2\end{array}$ & $\begin{array}{l}8 \\
4\end{array}$ & $\begin{array}{l}38.69 \\
38.04\end{array}$ & $\begin{array}{l}2.60 \\
2.15\end{array}$ & 0.65 & -2.73 & 4.02 & 0.43 & 10 & $0.68(\mathrm{NS})$ \\
\hline \multirow{2}{*}{ NA } & Height & $\begin{array}{l}1 \\
2\end{array}$ & $\begin{array}{l}8 \\
4\end{array}$ & $\begin{array}{l}36.09 \\
35.82\end{array}$ & $\begin{array}{l}1.20 \\
1.66\end{array}$ & 0.27 & -1.58 & 2.11 & 0.33 & 10 & $0.75(\mathrm{NS})$ \\
\hline & Width & $\begin{array}{l}1 \\
2\end{array}$ & $\begin{array}{l}8 \\
4\end{array}$ & $\begin{array}{l}23.11 \\
23.86\end{array}$ & $\begin{array}{l}1.60 \\
2.83\end{array}$ & -0.75 & -3.54 & 2.04 & $\begin{array}{c}- \\
0.60\end{array}$ & 10 & $0.56(\mathrm{NS})$ \\
\hline
\end{tabular}

Table 4. Comparison between gender in each state

\begin{tabular}{|c|c|c|c|c|c|c|c|c|c|c|c|c|}
\hline \multirow[t]{2}{*}{ State } & & & \multirow[t]{2}{*}{ Sex } & \multirow[t]{2}{*}{$\mathbf{N}$} & \multirow[t]{2}{*}{ Mean } & \multirow[t]{2}{*}{ SD } & \multirow[t]{2}{*}{$\begin{array}{c}\text { Mean } \\
\text { Difference }\end{array}$} & \multicolumn{2}{|c|}{$\begin{array}{l}\text { 95\% Confidence } \\
\text { Interval of the } \\
\text { Difference }\end{array}$} & \multirow[t]{2}{*}{$\mathbf{t}$} & \multirow[t]{2}{*}{ df } & \multirow[t]{2}{*}{ p-value } \\
\hline & & & & & & & & Lower & Upper & & & \\
\hline \multirow{12}{*}{1} & \multirow{3}{*}{$\begin{array}{c}\text { Height - } \\
\text { MS }\end{array}$} & Right & $\begin{array}{l}1 \\
2\end{array}$ & $\begin{array}{l}2 \\
8\end{array}$ & $\begin{array}{l}35.91 \\
34.73\end{array}$ & $\begin{array}{l}1.33 \\
2.35\end{array}$ & 1.18 & -2.91 & 5.28 & 0.67 & 8 & $0.52(\mathrm{NS})$ \\
\hline & & \multirow[t]{2}{*}{ Left } & 1 & 2 & 36.89 & 1.33 & \multirow[t]{2}{*}{0.84} & \multirow[t]{2}{*}{-3.89} & \multirow{2}{*}{5.58} & \multirow{2}{*}{0.41} & \multirow[t]{2}{*}{8} & \multirow{2}{*}{$0.69(\mathrm{NS})$} \\
\hline & & & 2 & 8 & 36.05 & 2.73 & & & & & & \\
\hline & \multirow{2}{*}{$\begin{array}{c}\text { Width - } \\
\text { MS }\end{array}$} & Right & $\begin{array}{l}1 \\
2\end{array}$ & $\begin{array}{l}2 \\
8\end{array}$ & $\begin{array}{l}29.13 \\
27.57\end{array}$ & $\begin{array}{l}5.67 \\
3.97\end{array}$ & 1.56 & -6.14 & 9.25 & 0.47 & 8 & $0.65(\mathrm{NS})$ \\
\hline & & Left & 1 & $\begin{array}{l}2 \\
8\end{array}$ & $\begin{array}{l}31.23 \\
28.10\end{array}$ & $\begin{array}{l}7.24 \\
3.56\end{array}$ & 3.13 & -4.52 & 10.79 & 0.94 & 8 & $0.37(\mathrm{NS})$ \\
\hline & & Dight & 1 & 2 & 37.76 & 2.55 & 0.65 & 405 & 625 & 027 & 8 & $080(\mathrm{NIS})$ \\
\hline & Depth - & Kignt & 2 & 8 & 37.11 & 3.14 & 0.05 & -4.95 & 0.25 & 0.21 & 8 & $0.80(\mathrm{NS})$ \\
\hline & MS & Left & 1 & 2 & 38.74 & 2.21 & 0.05 & -4.60 & 4.70 & 0.03 & 8 & $0.98(\mathrm{NS})$ \\
\hline & & & 2 & 8 & $\begin{array}{l}38.69 \\
38.49\end{array}$ & $\begin{array}{l}2.60 \\
269\end{array}$ & & & & & & \\
\hline & & Height & $\begin{array}{l}1 \\
2\end{array}$ & 8 & 36.09 & 1.20 & 2.40 & -0.27 & 5.08 & 2.07 & 8 & $0.07(\mathrm{NS})$ \\
\hline & NA & Width & 1 & 2 & 22.82 & 2.21 & 020 & 236 & 70 & - & 8 & 082 (NIC) \\
\hline & & Width & 2 & 8 & 23.11 & 1.60 & -0.29 & -3.36 & 2.19 & 0.22 & 8 & $0.83(\mathrm{NS})$ \\
\hline & Height - & Right & $\begin{array}{l}1 \\
2\end{array}$ & $\begin{array}{l}6 \\
4\end{array}$ & $\begin{array}{l}37.91 \\
33.02\end{array}$ & $\begin{array}{l}6.37 \\
3.90\end{array}$ & 4.89 & -3.41 & 13.18 & 1.36 & 8 & $0.21(\mathrm{NS})$ \\
\hline & MS & Joft & 1 & 6 & 38.95 & 3.50 & 437 & 052 & 025 & 206 & 8 & 007 (NS) \\
\hline & & Lent & 2 & 4 & 34.58 & 2.88 & 4.31 & -0.52 & 9.25 & 2.00 & 8 & $0.0 /(\mathrm{NS})$ \\
\hline & & Right & 1 & 6 & 28.41 & 4.69 & -122 & -713 & 470 & - & 8 & $065(\mathrm{NS}$ \\
\hline & Width - & Nigit & 2 & 4 & 29.62 & 2.31 & & & & 0.47 & & \\
\hline & MS & Left & 1 & $\begin{array}{l}6 \\
4\end{array}$ & $\begin{array}{l}29.86 \\
3170\end{array}$ & $\begin{array}{l}4.67 \\
257\end{array}$ & -1.94 & -7.91 & 4.04 & - & 8 & $0.48(\mathrm{NS})$ \\
\hline 2 & & & 1 & 6 & 40.17 & 3.62 & & & & & & \\
\hline & Depth - & Right & 2 & 4 & 37.99 & 3.55 & 2.18 & -3.16 & 7.53 & 0.94 & 8 & $0.37(\mathrm{NS})$ \\
\hline & MS & Left & 1 & 6 & 41.13 & 2.34 & 300 & 0 & 646 & 11 & 0 & \\
\hline & & Lent & 2 & 4 & 38.04 & 2.15 & 3.09 & -0.29 & 6.46 & 2.11 & 8 & $0.0 /(\mathrm{NS})$ \\
\hline & & Height & 1 & 6 & 41.58 & 4.22 & 576 & 057 & 1095 & 256 & 8 & $003 *$ \\
\hline & NA & & 2 & 4 & 35.82 & 1.66 & & & & & & \\
\hline & & Width & 1 & 6 & 25.48 & 2.08 & 162 & -1.94 & 5.17 & 1.05 & 8 & $0.32(\mathrm{NS})$ \\
\hline & & & 2 & 4 & 23.86 & 2.83 & & & & & & \\
\hline
\end{tabular}

Independent sample t test $\quad{ }^{*} \mathrm{p}<0.05$ Statistically Significant $\mathrm{p}>0.05$ Non Significant, NS

\section{Comparison between of the two states}

Of the two states, the subjects from Karnataka had the have highest mean morphometric measurements for most of the parameters, except for Width - maxillary sinus (MS): Right, Width MS: Left among the males. The mean Height MS: Right, Height - MS: Left, Depth - MS: left and nasal aperture (NA): Height was observed to be higher among the females than the males for the subjects from Kerala (Table 3).

\section{Sexual dimorphism of the parameters in both of the states}

The male subjects from Karnataka had higher mean values than the females for all the parameters except NA: Width, which was higher among the females. The male subjects from 
Kerala also had higher mean values than the females for all the parameters except Width - MS: Right and Width - MS: Left (Table 3).

The correlation between gender in each state showed a significant $\mathrm{p}$ value for NA: Height between the sexes of the subjects from Kerala
(Table 4). The correlation between the NA and MS variables according to gender and state showed a significant $\mathrm{p}$ value between the parameters Width - NA of the females subjects from Karnataka and Height - MS of Left side (Table 5).

Table 5. Correlation between nasal aperture and maxillary sinus variables according to gender and state.

\begin{tabular}{|c|c|c|c|c|c|c|c|c|c|}
\hline \multirow{2}{*}{ State } & \multirow{2}{*}{ Sex } & & & \multicolumn{2}{|c|}{ Height - MS } & \multicolumn{2}{|c|}{ Width - MS } & \multicolumn{2}{|c|}{ Depth - MS } \\
\hline & & & & Right & Left & Right & Left & Right & Left \\
\hline \multirow{8}{*}{1} & \multirow{4}{*}{1} & \multirow{2}{*}{ Height - NA } & $\mathbf{r}$ & -1.00 & -1.00 & -1.00 & -1.00 & -1.00 & -1.00 \\
\hline & & & p-value & . & & & & & \\
\hline & & \multirow{2}{*}{ Width - NA } & $\mathbf{r}$ & -1.00 & -1.00 & -1.00 & -1.00 & -1.00 & -1.00 \\
\hline & & & p-value & . & . & & & . & \\
\hline & \multirow{4}{*}{2} & \multirow{2}{*}{ Height - NA } & $\mathbf{r}$ & 0.30 & -0.04 & 0.24 & 0.25 & -0.22 & 0.15 \\
\hline & & & p-value & $0.47(\mathrm{NS})$ & $0.93(\mathrm{NS})$ & $0.57(\mathrm{NS})$ & $0.56(\mathrm{NS})$ & $0.60(\mathrm{NS})$ & $0.72(\mathrm{NS})$ \\
\hline & & \multirow{2}{*}{ Width - NA } & $\mathbf{r}$ & -0.32 & -0.75 & 0.37 & 0.28 & 0.05 & 0.39 \\
\hline & & & p-value & $0.45(\mathrm{NS})$ & $0.03 *$ & $0.37(\mathrm{NS})$ & $0.50(\mathrm{NS})$ & $0.91(\mathrm{NS})$ & $0.34(\mathrm{NS})$ \\
\hline \multirow{8}{*}{2} & \multirow{4}{*}{1} & \multirow{2}{*}{ Height - NA } & $\mathbf{r}$ & -0.57 & -0.59 & -0.59 & -0.37 & -0.74 & -0.72 \\
\hline & & & p-value & $0.24(\mathrm{NS})$ & $0.22(\mathrm{NS})$ & $0.22(\mathrm{NS})$ & $0.47(\mathrm{NS})$ & $0.09(\mathrm{NS})$ & $0.11(\mathrm{NS})$ \\
\hline & & \multirow{2}{*}{ Width - NA } & $\mathbf{r}$ & 0.42 & 0.45 & 0.35 & 0.27 & 0.24 & 0.34 \\
\hline & & & p-value & $0.41(\mathrm{NS})$ & $0.37(\mathrm{NS})$ & $0.50(\mathrm{NS})$ & $0.60(\mathrm{NS})$ & $0.65(\mathrm{NS})$ & $0.52(\mathrm{NS})$ \\
\hline & \multirow{4}{*}{2} & \multirow{2}{*}{ Height - NA } & $\mathbf{r}$ & -0.08 & -0.55 & -0.48 & -0.58 & 0.14 & -0.75 \\
\hline & & & p-value & $0.92(\mathrm{NS})$ & $0.45(\mathrm{NS})$ & $0.52(\mathrm{NS})$ & $0.42(\mathrm{NS})$ & $0.86(\mathrm{NS})$ & $0.25(\mathrm{NS})$ \\
\hline & & \multirow{2}{*}{ Width - NA } & $\mathbf{r}$ & -0.44 & 0.28 & -0.58 & 0.93 & -0.31 & -0.06 \\
\hline & & & p-value & $0.56(\mathrm{NS})$ & $0.72(\mathrm{NS})$ & $0.42(\mathrm{NS})$ & $0.07(\mathrm{NS})$ & $0.69(\mathrm{NS})$ & $0.94(\mathrm{NS})$ \\
\hline
\end{tabular}

Pearsons correlation test $* \mathrm{p}<0.05$ Statistically Significant

$\mathrm{p}>0.05$ Non Significant, NS

The correlation between the NA and MS variables in each state showed a statistically significant $\mathrm{p}$ value with respect to Width - NA and Height -

Table 6. Correlation between nasal aperture and maxillary sinus variables in each state.

\begin{tabular}{|c|c|c|c|c|c|c|c|c|}
\hline \multirow{2}{*}{ State } & & & \multicolumn{2}{|c|}{ Height - MS } & \multicolumn{2}{|c|}{ Width - MS } & \multicolumn{2}{|c|}{ Depth - MS } \\
\hline & & & Right & Left & Right & Left & Right & Left \\
\hline \multirow{4}{*}{1} & & $\mathbf{r}$ & 0.21 & -0.03 & -0.02 & -0.002 & -0.23 & -0.06 \\
\hline & Height - NA & p-value & $0.57(\mathrm{NS})$ & $0.93(\mathrm{NS})$ & $0.95(\mathrm{NS})$ & $0.99(\mathrm{NS})$ & $0.53(\mathrm{NS})$ & $0.86(\mathrm{NS})$ \\
\hline & & $\mathbf{r}$ & -0.38 & -0.74 & 0.05 & -0.10 & -0.10 & 0.19 \\
\hline & Width - NA & p-value & $0.28(\mathrm{NS})$ & $.02 *$ & $0.88(\mathrm{NS})$ & $0.78(\mathrm{NS})$ & $0.78(\mathrm{NS})$ & $0.61(\mathrm{NS})$ \\
\hline \multirow{4}{*}{2} & & $\mathbf{r}$ & -0.04 & 0.06 & -0.53 & -0.45 & -0.17 & -0.006 \\
\hline & Height - NA & p-value & $0.91(\mathrm{NS})$ & $0.88(\mathrm{NS})$ & $0.11(\mathrm{NS})$ & $0.19(\mathrm{NS})$ & $0.64(\mathrm{NS})$ & $0.99(\mathrm{NS})$ \\
\hline & Width - NA & $\mathbf{r}$ & 0.26 & 0.49 & 0.01 & 0.31 & 0.10 & 0.33 \\
\hline & Width - NA & p-value & $0.48(\mathrm{NS})$ & $0.15(\mathrm{NS})$ & $0.98(\mathrm{NS})$ & $0.39(\mathrm{NS})$ & $0.78(\mathrm{NS})$ & $0.35(\mathrm{NS})$ \\
\hline
\end{tabular}

Pearsons correlation test

$* \mathrm{p}<0.05$ Statistically Significant $\mathrm{p}>0.05$ Non Significant, NS

MS of the Left side in the subjects from

Karnataka (Table 6).

The cCorrelation between the NA and MS

variables in both genders showed no statistically

significant results between the groups (Table 7).

Table 7. Correlation between nasal aperture and maxillary sinus variables in each gender.

\begin{tabular}{|c|c|c|c|c|c|c|c|c|}
\hline \multirow{2}{*}{ Sex } & & & \multicolumn{2}{|c|}{ Height - MS } & \multicolumn{2}{|c|}{ Width - MS } & \multicolumn{2}{|c|}{ Depth - MS } \\
\hline & & & Right & Left & Right & Left & Right & Left \\
\hline \multirow{4}{*}{1} & & $\mathbf{r}$ & -0.46 & -0.43 & -0.61 & -0.46 & -0.55 & -0.45 \\
\hline & Helght - NA & p-value & $0.25(\mathrm{NS})$ & $0.29(\mathrm{NS})$ & $0.11(\mathrm{NS})$ & $0.25(\mathrm{NS})$ & $0.16(\mathrm{NS})$ & $0.26(\mathrm{NS})$ \\
\hline & & $\mathbf{r}$ & 0.37 & 0.43 & 0.02 & -0.10 & 0.24 & 0.33 \\
\hline & Width - NA & p-value & $0.37(\mathrm{NS})$ & $0.29(\mathrm{NS})$ & $0.96(\mathrm{NS})$ & $0.81(\mathrm{NS})$ & $0.57(\mathrm{NS})$ & $0.43(\mathrm{NS})$ \\
\hline \multirow{4}{*}{2} & Hoinht NA & $\mathbf{r}$ & 0.13 & -0.19 & 0.02 & -0.05 & -0.09 & -0.12 \\
\hline & Height - NA & p-value & $0.68(\mathrm{NS})$ & $0.55(\mathrm{NS})$ & $0.96(\mathrm{NS})$ & $0.87(\mathrm{NS})$ & $0.78(\mathrm{NS})$ & $0.70(\mathrm{NS})$ \\
\hline & & $\mathbf{r}$ & -0.42 & -0.31 & 0.12 & 0.49 & -0.09 & 0.17 \\
\hline & Width - NA & p-value & $0.18(\mathrm{NS})$ & $0.32(\mathrm{NS})$ & $0.72(\mathrm{NS})$ & $0.11(\mathrm{NS})$ & 0.79 (NS) & $0.59(\mathrm{NS})$ \\
\hline
\end{tabular}




\section{DISCUSSION}

As an individual grows, adaptive changes in human nasal aperture morphology directly affect the maxillary sinus morphology. Various populations present with different ethnicities, racial changes and exposures to different climates, which directly affect the osteometric morphology of the human skeleton. ${ }^{3}$ To date, very few studies have investigated the correlation between the nasal/piriform aperture morphology and the maxillary sinus morphology. These variations in morphology can be used for sexual dimorphism and forensic identification.

In the present study, statistical analysis was done by calculating the mean and standard deviation measurements of both the nasal apertures and maxillary sinuses, which were calculated and correlated. In this paper, we discuss the parameters that showed statistically significant results when correlated between the groups.

Different populations exhibit various osteometric morphological patterns of sexual dimorphism, as documented in several studies. ${ }^{4-6}$ In our study, mean morphometric measurements were higher in the subjects from the state of Karnataka in reference to all of the parameters in both states, except for Width - MS: Right and Width - MS: Left among the males. The Height MS: Right, Height - MS: Left, Depth - MS: left and NA: Height was observed to be higher in the female subjects from Kerala in comparison to the male subjects from that state.

The male subjects from Karnataka had higher mean values than the female subjects for all the parameters except NA: Width, which was higher among the females. The male subjects from Kerala also had higher mean values than the females from that state for all the parameters, except the MS Width: Right and MS Width: Left. Similar findings were reported by Banik, who found that the mean values of craniometric characteristics were higher in male skulls than in female skulls among a West Bengal population. ${ }^{7}$ Tambawala et al. showed statistically significantly lower values for both the left and right MS among females in relation to the MS dimensions. ${ }^{8}$ Sexual dimorphism has been studied with piriform apertures in various populations. ${ }^{9,10}$

Facial features based on the parameters of the skull aid in forensic facial reconstruction. Strapasson evaluated the relationships between alar cartilage, piriform aperture, nose morphology and facial typology. ${ }^{11}$ That study's findings showed that nasal width was associated with decreased width of the piriform aperture, the skeletal vertical pattern of the face, sex and age. The results of our study are in partial agreement with those results (Tables 4-7). The study by Strapasson suggested that forensic facial guidelines can be improved by establishing a correlation between the alar cartilages and the biological profile characteristics of a given population. Very few studies in the literature have investigated this topic in this context. Hence, we conducted this pilot study to establish a correlation that could be used for sexual dimorphism, individual identification and as a guide for forensic facial reconstruction.

\section{CONCLUSIONS}

This study has shown that the dimensions of MS and NA in the population from the states of Karnataka and Kerala in India may be used to estimate sex. The measurements may also be used for ethnic differentiation during human identification and provide data for forensic facial reconstruction. Consequently, it is recommended that a future study be conducted with a larger sample size to derive an equation so the data may be used to determine an individual's sex and aid in forensic identification and facial reconstruction.

\section{CONFLICT OF INTEREST STATEMENT}

None

\section{FINANCIAL ASSISTANCE}

We are thankful to Nitte deemed to be University for sanction of Rs. 1,20,000 vide Nitte Research Project Number NUFR2/2018/10/12 with application ID: NUFR18B-007.

\section{ACKNOWLEDGEMENT}

We would also like to thank Dr Vinayak Kamath, Senior lecturer, Department of Public Health 
Dentistry, Government Dental College, Goa for compiling the statistics.

\section{REFERENCES}

1. Prabhat M, Rai S, Kaur M, Prabhat K, Bhatnagar P, Panjwani S. Computed tomography based forensic gender determination by measuring the size and volume of the maxillary sinuses. J Forensic Dent Sci. 2016;8(1):40-46.

2. Uthman AT, Al-Rawi NH, Al-Naaimi AS, AlTimimi JF. Evaluation of maxillary sinus dimensions in gender determination using helical $\mathrm{CT}$ scanning. $\mathrm{J}$ Forensic Sci. 2011;56(2):403-408.

3. Asghar A, Dixit A, Rani M. Morphometric Study of Nasal Bone and Piriform Aperture in Human Dry Skull of Indian Origin. J Clin Diagn Res. 2016;10(1):AC05AC7.

4. Bastir M, Godoy P, Rosas A. Common features of sexual dimorphism in the cranial airways of different human populations. Am J Phys Anthropol. 2011;146(3):414-422.

5. Moreddu E, Puymerail L, Michel J, Achache M, Dessi P, Adalian P. Morphometric measurements and sexual dimorphism of the piriform aperture in adults. Surg Radiol Anat. 2013;35(10):917-924.

6. Strapasson RAP, Herrera LM, Melani RFH. Forensic Facial Reconstruction: Relationship Between the Alar Cartilage and Piriform Aperture. J Forensic Sci. 2017;62(6):1460-1465.
7. Urooge A, Patil BA. Sexual Dimorphism of Maxillary Sinus: A Morphometric Analysis using Cone Beam Computed Tomography. J Clin Diagn Res. 2017;11(3): ZC67-ZC70.

8. Banik SD. Sexual Dimorphism in Craniometric Characteristics of Occipital Bone in Adult Human Skulls from West Bengal, India. J. Life Sci. 2017;9: 1:28-32.

9. Tambawala SS, Karjodkar FR, Sansare K, Prakash N. Sexual dimorphism of maxillary sinus using cone beam computed tomography. Egypt J Forensic Sci. 2015;6(2):120-125.

10. Moreddu E, Puymerail L, Michel J, Achache M, Dessi P, Adalian P. Morphometric measurements and sexual dimorphism of the piriform aperture in adults. Surg Radiol Anat. 2013 Dec;35(10):917-924.

11. Abdelaleem SA, Younis R H.A., Kader MA. Sex determination from the piriform aperture usingmulti slice computed tomography: Discriminant function analysis of Egyptian population in Minia Governorat. Egypt J Forensic Sci. 2016; 6 (4): 429-434.

12. Strapasson RAP, Herrera LM, Melani RFH. Forensic Facial Reconstruction: Relationship Between the Alar Cartilage and Piriform Aperture. J Forensic Sci. 2017;62(6):1460-1465. 